\title{
PENGARUH ISLAMIC BRANDING DAN PERILAKU RELIGIUS TERHADAP KEPUASAN NASABAH PADA BSM PALU
}

\author{
Gina Khairunnisa \\ Zakiyah Zahara \\ Program Studi S1 Manajemen, Fakultas Ekonomi dan Bisnis, Universitas Tadulako \\ E-mail: ginanisaica@gmail.com; zakiyah66.zm@gmail.com
}

\begin{abstract}
This study aims to analyze the influence of Islamic branding and religious behavior on customer satisfaction Bank Syariah Mandiri Palu. The research method used is a causal descriptive method with a sample of 60 people. The form of sampling in this study is non-probability with a purposive sampling technique. The analytical method used in this study is Partial Least Square (PLS) with the help of the SmartPLS 3.0 statistical program. The results showed that Islamic branding had a significant effect on customer satisfaction of Bank Syariah Mandiri Palu while religious behavior did not significantly influence customer satisfaction at Bank Syariah Mandiri Palu.
\end{abstract}

\section{Keyword: Islamic Branding, Religious Behavior, Customer Satisfaction}

\section{PENDAHULUAN}

Perbankan Syariah terbentuk pertama kali di Indonesia pada tahun 1992 dan saat ini sudah banyak pencapaian kemajuan yang didapatkan, baik dari sistem pengawasan, aspek kelembagaan, infrastruktur penunjang, perangkat regulasi maupun awareness serta literasi masyarakat terhadap layanan jasa keuangan syariah. Pesatnya pertumbuhan perbankan syariah Indonesia ini ditandai meningkatnya jumlah Bank Usaha Syariah dalam 10 tahun terakhir.

Berdasarkan data yang dihimpun dari Otoritas Jasa Keuangan tahun 2019, telah tercatat jumlah Bank Usaha Syariah (BUS) mengalami peningkatan yang cukup signifikan selama periode 2009-2019. Tahun 2009 hanya terdapat 6 BUS dan tahun 2019 telah mencapai 14 BUS yang juga diikuti dengan pertumbuhan UUS (Unit Usaha Syariah) yang juga meningkat dengan pangsa pasar mencapai 4.61\% (www.ojk.go.id, 2019).

Maju dan tidaknya industri perbankan syariah berada di tangan para pihak yang secara langsung atau tidak langsung merasakan manfaat kehadirannya (Zahara, 2011:627). Perbankan syariah perlu untuk merumuskan sebuah strategi dalam memenangkan pasar. Sebuah grand strategi yang membentuk citra baru perbankan syariah nasional yang bersifat inklusif, universal serta sebuah strategi komunikasi yang memposisikan perbankan syariah bukan hanya sekedar bank tetapi juga sebagai mitra hidup masyarakat yang sejalan dengan prinsip-prinsip Islam dan tata cara operasional yang sesuai dengan tuntunan Al-Qur'an dan Al-hadist.

Untuk memenuhi keinginan konsumen muslim secara lahir dan batin ketika ingin membeli dan mengkonsumsi produk maupun jasa, perusahaan harus mencantumkan keterangan yang berhubungan dengan produk dan salah satu strategi yang diterapkan adalah Islamic branding. Islamic branding diartikan sebagai penambahan kata syariah, nama-nama Islam, label halal ketika memasarkan produk tersebut. Menurut Minkus-McKenna dalam Yusof dan Jusoh (2014:180) Islamic brands atau halal brands dibuat sesuai dengan prinsip-prinsip Islam yang menuntun apa yang diperbolehkan tidak hanya di industri makanan tetapi juga di kosmetik, farmasi, logistik, pakaian, keuangan, perhotelan dan perbankan.

Dalam hafiz (2017:2) dikemukakan bahwa Islamic branding tidak dapat dipisahkan dengan iman, setiap tindakan harus didasari konsep ketuhanan bahwa mencintai ataupun membenci bukan karena keinginan manusiawi, tapi karena didasari rasa cintanya kepada Allah SWT. Konsumen 


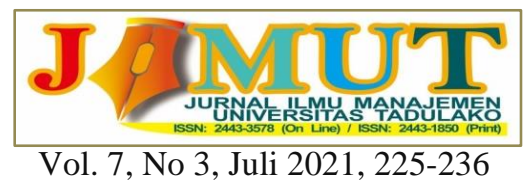

muslim dalam setiap aktivitasnya tidak terlepas dari perilaku religiusnya, termasuk dalam mengkonsumsi suatu produk atau jasa. Seorang yang menjadikan aturan agama sebagai aturan hidupnya akan merasa perlu mempertimbangkan segala tindakannya yang sesuai dengan syariat.

Perkembangan industri perbankan mulai berakibat pada tingkat persaingan yang tinggi, menyebabkan perubahan standar nasabah dalam memilih jasa perbankan yang akan digunakan. Maka untuk memenangkan persaingan, bank syariah perlu mengoptimalkan usahanya dalam memberikan kepuasan kepada nasabah. Ketika nasabah merasa puas maka akan terjalin hubungan yang harmonis antara pihak bank dengan nasabah, membentuk loyalitas nasabah serta berimbas pada perusahaan yang mampu memenangkan persaingan pasar. Kepuasan konsumen diartikan sebagai kesesuaian antara persepsi atas produk/jasa yang distandarkan oleh konsumen dengan kenyataan yang diterima oleh kosumen. Tujuan dari penelitian ini adalah untuk menganalisis pengaruh dari Islamic branding dan perilaku religius terhadap kepuasan nasabah pada salah satu bank syariah yaitu Bank Syariah Mandiri di kota Palu.

\section{LANDASAN TEORI}

\section{Pemasaran}

Menurut Kotler dan Armstrong (2013:29) "Marketing is the process by which companies create value for customers and build strong customer relationship in order to capture value from customers in return" yang jika diartikan yaitu pemasaran adalah suatu proses yang dimana perusahaan berusaha menciptakan nilai bagi pelanggan serta menjalin hubungan pelanggan yang kuat agar mendapatkan nilai dari pelanggan.

\section{Kepuasan Konsumen}

Menurut Biesok dan Wrobel (2011:24) kepuasan tidak hanya mencakup perasaan yang terkait dengan proses pembelian, tetapi juga suasana sebelum dan sesudah eksekusi pembelian. Keadaan kepuasan atau ketidakpuasan adalah perasaan subyektif dan merupakan hasil pengalaman spesifik dari persepsi dan emosi individu.

Menurut Biesok dan Wrobel (2011:27), ada 3 atribut yang digunakan untuk mengukur kepuasan pelanggan:

1. Atribut yang terkait produk/layanan, yaitu: harga melebihi harapan, memenuhi persyaratan orientasi dan produsen yang ramah pelanggan.

2. Atribut yang terkait proses pembelian, yaitu: merencanakan pembelian, promosi, citra penjual, layanan pelanggan, harapan yang diperjelas serta proses pengambilan keputusan yang diperpanjang.

3. Atribut yang terkait perasaan, yaitu: emosi positif, pengalaman pelanggan, penegasan produk, persepsi nilai barang, persepsi kualitas barang, menyenangkan dan loyalitas.

\section{Islamic Branding}

Berdasarkan pendapat Nasrullah (2015) bahwa Islamic branding dapat didefinisikan sebagai pemanfaatan nama-nama yang berkaitan dengan Islam atau menunjukkan identitas halal terhadap sebuah produk.

Mourad dan Karanshawy (2013:154) mengklasifikasikan dimensi Islamic branding menjadi 4, antara lain:

1. Dimensi merek fungsional, yang merupakan persepsi manfaat yang terkait dengan merek. Dalam dimensi ini mengenai bagaimana merek Islami tersebut memberikan manfaat kepada elemen-elemen perusahaan yang dalam praktiknya sesuai dengan nilai-nilai Islami. Dimensi 
ini mengenai bagaimana perusahaan yang memiliki merek Islami menjalankan fungsinya sebagai perusahaan yang produk, layanan ataupun operasionalnya berbasis syariah.

2. Dimensi merek sosial, yang merupakan kemampuan merek Islami tersebut untuk membuat identifikasi kepada masyarakat. Dimensi merek sosial menunjukkan identitas merek Islami pada perusahaan yang tercermin pada penampilan staf yang menunjukan profesionalitas, pelayan yang ramah, bersahabat serta citra sosial perusahaan di masyarakat.

3. Dimensi merek mental, merupakan kemampuan merek untuk mendukung pribadi individu dalam hal ini adalah konsumen. Dimensi mental menunjukkan bagaimana merek Islami tersebut mempengaruhi pribadi konsumen.

4. Dimensi merek spiritual, merupakan persepsi atas tanggung jawab sosial yang didasari atas merek Islami. Perusahaan yang memaknai pengelolaan perusahaan sebagai bagian dari ibadah kepada Tuhan, menegaskan bahwa keberadaan perusahaaan diperlukan untuk melayani kebutuhan masyarakat. Salah satu dari beberapa penentu dari merek Islami adalah dengan menjadi perusahaan yang bermanfaat bagi masyarakat luas. Oleh karena itu merek perlu mencerminkan dimensi merek spiritual dengan tanggung jawab sosial sebagai salah satu penentu utama.

\section{Perilaku Religius}

Menurut Mokhlis (2009:76) religiusitas adalah sejauh mana kepercayaan pada nilai-nilai dan cita-cita agama tertentu dipegang dan dipraktikkan oleh seorang individu. Menurut Glock dan Stark dalam Nasrullah (2015:82), ada lima dimensi religiusitas yaitu:

1) Dimensi keyakinan/ ideologi, dimensi ini berdasar pada konsep tauhid atau pengakuan atas ke-Esaan Tuhan. Dimensi keyakinan ini merujuk pada tingkat keyakinan seseorang terhadap kebenaran atas ajaran agama yang dianut dan bagaimana seorang yang religius mengakui dan berpegang teguh terhadap pandangan agama tersebut. Namun pada umumnya esensi pengharapan setiap agama itu sama walaupun terkadang berbeda doktrin.

2) Dimensi praktik, dimensi ini berisi berbagai peribadatan atau ritual yang dilakukan seorang yang religius sebagai bentuk ketaatan dan komitmen atas agama yang dianutnya. Dimensi praktik ini dibagi menjadi dua bagian yaitu ritual dan ketaatan.

3) Dimensi pengalaman, dimensi ini berkaitan dengan pengalaman religi seseorang yang dapat berupa perasaan, persepsi dan sensasi yang dialami mengenai suatu esensi ketuhanan.

4) Dimensi pengetahuan agama, dimensi ini merujuk pada tingkat pengetahuan seseorang terhadap ajaran pokok agamanya berupa dasar-dasar keyakinan, kitab suci dan ritual/peribadatan agama yang dianut.

5) Dimensi konsekuensi, dimensi ini mengacu pada perilaku seseorang melalui identifikasi akibat dari keyakinan keagamaan, praktik, pengalaman dan pengetahuan agamanya. Dimensi ini tercermin melalui perilaku seseorang yang berusaha menjalankan segala perintah Tuhan dan menghindari perbuatan yang dilarang dalam ajaran agamanya. Perilaku ini dapat melalui berbagai sikap yang berusaha untuk tidak menyimpang dari norma-norma kehidupan dan aturan-aturan lembaga pemerintah sebagai pemimpin mereka disuatu negara.

\section{Hipotesis}

H1: Islamic branding berpengaruh positif dan signifikan terhadap kepuasan nasabah Bank Syariah Mandiri di Kota Palu.

H2: Perilaku religius berpengaruh positif dan signifikan terhadap kepuasan nasabah Bank Syariah Mandiri di Kota Palu. 


\section{METODE PENELITIAN}

Populasi penelitian ini adalah seluruh nasabah Bank Syariah Mandiri di Kota Palu. Penelitian ini dilakukan dengan membagikan kuesioner kepada 60 responden dengan teknik purposive sampling. Pengumpulan data dilakukan dengan cara memberikan kuisioner yang berisi pertanyaan-pertanyaan terstruktur kepada para responden dengan menggunakan skala Likert dengan 5 tingkat jawaban mulai dari sangat setuju (5) sampai sangat tidak setuju (1). Alat analisis yang digunakan pada penelitian ini yaitu Partial Least Square (PLS). Analisis Partial Least Square menggunakan Software SmartPLS 3. Menurut Usada et al., (2016) dalam PLS Path Modeling terdapat dua model pengukuran yang digunakan yaitu outer model dan inner model.

\section{HASIL DAN PEMBAHASAN}

\section{Outer Model}

Outer model berfokus pada hubungan antar variabel laten dengan indikator-indikatornya dan mendeskripsikan tentang bagaimana indikator yang ada berhubungan dengan variabel laten. Model pengukuran outer model digunakan untuk menguji validitas dan reliabilitas instrumen dalam penelitian ini.

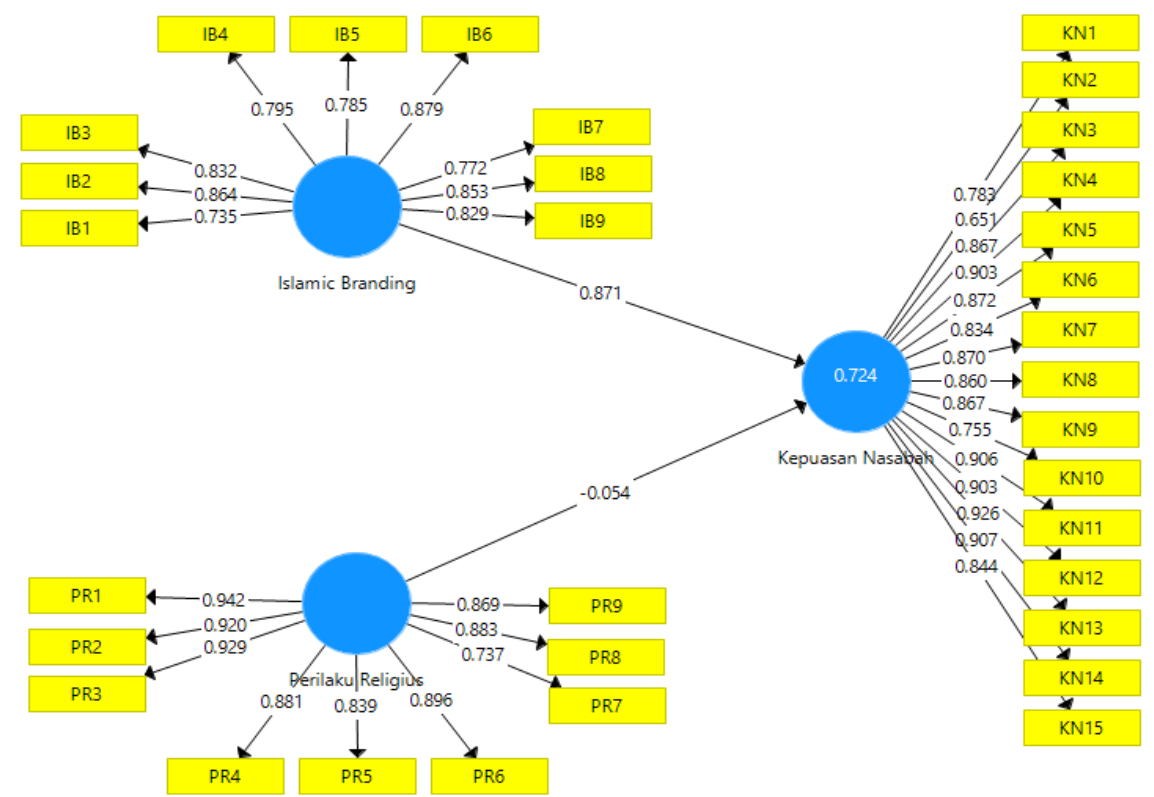

Gambar 1

Output Outer Model

\section{Convergent Validity}

Sumber : PLSalgoritm, 2019

Ukuran refleksif individual dikatakan tinggi jika berkorelasi lebih dari 0.70 dengan konstruk yang diukur. Jika nilai loading factor kurang dari 0.70 maka akan dilakukan modifikasi dengan menghilangkan indikator tersebut.

Tabel 1

Outer Loadings (Meaurement Model)

\begin{tabular}{|c|c|r|r|r|r|}
\hline & \multicolumn{2}{|c|}{ Model Awal } & Modifikasi & & \multicolumn{2}{c|}{ Model Awal } & \multicolumn{1}{c|}{ Modifikasi } \\
\hline & \multicolumn{2}{|c|}{ Islamic Branding } & & \multicolumn{2}{|c|}{ Kepuasan Nasabah } \\
\hline IB 1 & 0.735 & 0.734 & KN 1 & 0.783 & 0.767 \\
\hline IB 2 & 0.864 & 0.861 & KN 2 & $\mathbf{0 . 6 5 1}$ & \\
\hline IB 3 & 0.832 & 0.832 & KN 3 & 0.867 & 0.873 \\
\hline IB 4 & 0.795 & 0.797 & KN 4 & 0.903 & 0.905 \\
\hline IB 5 & 0.785 & 0.789 & KN 5 & 0.872 & 0.871 \\
\hline
\end{tabular}




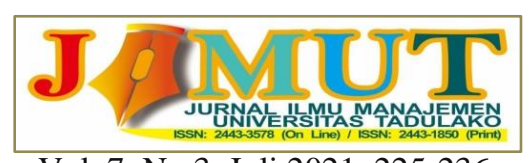

Vol. 7, No 3, Juli 2021, 225-236

\begin{tabular}{|c|r|r|r|r|r|}
\hline IB 6 & 0.879 & 0.881 & KN 6 & 0.834 & 0.837 \\
\hline IB 7 & 0.772 & 0.769 & KN 7 & 0.870 & 0.877 \\
\hline IB 8 & 0.853 & 0.850 & KN 8 & 0.860 & 0.871 \\
\hline IB 9 & 0.829 & 0.828 & KN 9 & 0.867 & 0.870 \\
\hline & Perilaku Religius & & KN 10 & 0.755 & 0.757 \\
\hline PR 1 & 0.942 & 0.942 & KN 11 & 0.906 & 0.907 \\
\hline PR 2 & 0.920 & 0.921 & KN 12 & 0.903 & 0.905 \\
\hline PR 3 & 0.929 & 0.930 & KN 13 & 0.926 & 0.923 \\
\hline PR 4 & 0.881 & 0.881 & KN 14 & 0.907 & 0.911 \\
\hline PR 5 & 0.839 & 0.839 & KN 15 & 0.844 & 0.850 \\
\hline PR 6 & 0.896 & 0.896 & & & \\
\hline PR 7 & 0.737 & 0.734 & & & \\
\hline PR 8 & 0.883 & 0.883 & & & \\
\hline PR 9 & 0.869 & 0.868 & & & \\
\hline
\end{tabular}

Sumber : Pengolahan data dengan PLS, 2019

Hasil pengolahan data dengan menggunakan Smart PLS dapat dilihat pada Tabel 1 yang pada awalnya nilai outer model belum memenuhi convergent validity karena masih ada indikator yang memiliki nilai loading factor dibawah 0.70. Kemudian modifiksi model dilakukan dengan mengeluarkan indikator yang memiliki nilai loading factor di bawah 0.70 sehingga dengan model modifikasi seperti di Tabel 1 menunjukkan bahwa semua nilai loading factor telah memiliki nilai di atas 0.70 sehingga konstruk untuk semua variabel sudah tidak ada yang dieliminasi dari model tersebut.

\section{Disciminant Validity}

Nilai ini merupakan nilai cross loading factor yang berguna untuk mengetahui apakah konstruk memiliki deskriminan yang memadai yaitu dengan cara membandingkan nilai loading pada konstruk yang dituju harus lebih besar dibandingkan dengan nilai loading konstruk lain.

Tabel 2

Dicriminant Validity (Cross Loading)

\begin{tabular}{|l|r|r|r|}
\hline & Islamic Branding & Perilaku Religius & \multicolumn{1}{c|}{ Kepuasan Nasabah } \\
\hline IB 1 & $\mathbf{0 . 7 3 4}$ & 0.207 & 0.714 \\
\hline IB 2 & $\mathbf{0 . 8 6 1}$ & 0.357 & 0.615 \\
\hline IB 3 & $\mathbf{0 . 8 3 2}$ & 0.182 & 0.650 \\
\hline IB 4 & $\mathbf{0 . 7 9 7}$ & 0.477 & 0.747 \\
\hline IB 5 & $\mathbf{0 . 7 8 9}$ & 0.359 & 0.783 \\
\hline IB 6 & $\mathbf{0 . 8 8 1}$ & 0.318 & 0.791 \\
\hline IB 7 & $\mathbf{0 . 7 6 9}$ & 0.122 & 0.586 \\
\hline
\end{tabular}

Tabel 2

Dicriminant Validity (Cross Loading) (Lanjutan)

\begin{tabular}{|l|r|r|r|}
\hline & Islamic Branding & Perilaku Religius & Kepuasan Nasabah \\
\hline IB 8 & $\mathbf{0 . 8 5 0}$ & 0.379 & 0.599 \\
\hline IB 9 & $\mathbf{0 . 8 2 8}$ & 0.464 & 0.568 \\
\hline PR 1 & 0.399 & $\mathbf{0 . 9 4 2}$ & 0.299 \\
\hline PR 2 & 0.436 & $\mathbf{0 . 9 2 1}$ & 0.942 \\
\hline PR 3 & 0.400 & $\mathbf{0 . 9 3 0}$ & 0.297 \\
\hline PR 4 & 0.304 & $\mathbf{0 . 8 8 1}$ & 0.274 \\
\hline PR 5 & 0.340 & $\mathbf{0 . 8 3 9}$ & 0.222 \\
\hline PR 6 & 0.316 & $\mathbf{0 . 8 9 6}$ & 0.225 \\
\hline PR 7 & 0.270 & $\mathbf{0 . 7 3 5}$ & 0.177 \\
\hline PR 8 & 0.297 & $\mathbf{0 . 8 8 3}$ & 0.189 \\
\hline PR 9 & 0.293 & $\mathbf{0 . 8 6 8}$ & 0.232 \\
\hline KN 1 & 0.821 & 0.286 & $\mathbf{0 . 7 6 7}$ \\
\hline KN 3 & 0.761 & 0.369 & $\mathbf{0 . 8 7 3}$ \\
\hline KN 4 & 0.780 & 0.264 & $\mathbf{0 . 9 0 5}$ \\
\hline KN 5 & 0.659 & 0.162 & $\mathbf{0 . 8 7 1}$ \\
\hline KN 6 & 0.719 & 0.387 & $\mathbf{0 . 8 3 7}$ \\
\hline
\end{tabular}




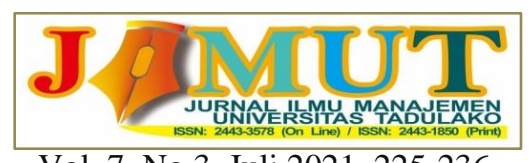

Vol. 7, No 3, Juli 2021, 225-236

\begin{tabular}{|l|r|r|r|}
\hline KN 7 & 0.733 & 0.437 & $\mathbf{0 . 8 7 7}$ \\
\hline KN 8 & 0.642 & 0.174 & $\mathbf{0 . 8 7 1}$ \\
\hline KN 9 & 0.678 & -0.013 & $\mathbf{0 . 8 7 0}$ \\
\hline KN 10 & 0.514 & -0.083 & $\mathbf{0 . 7 5 7}$ \\
\hline KN 11 & 0.746 & 0.096 & $\mathbf{0 . 9 0 7}$ \\
\hline KN 12 & 0.673 & 0.354 & $\mathbf{0 . 8 5 0}$ \\
\hline KN 13 & 0.818 & 0.369 & $\mathbf{0 . 9 2 3}$ \\
\hline KN 14 & 0.806 & 0.395 & $\mathbf{0 . 9 1 1}$ \\
\hline KN 15 & 0.673 & 0.354 & $\mathbf{0 . 8 5 0}$ \\
\hline
\end{tabular}

Sumber : Pengolahan data dengan PLS, 2019

Pada Tabel 2 dapat disimpulkan bahwa variabel Islamic branding dengan indikatornya (IB1IB9) lebih tinggi dibandingkan korelasi IB1-IB9 dengan variabel lainnya yaitu perilaku religius dan kepuasan nasabah. Hal ini juga berlaku pada variabel perilaku religius dengan indikatornya (PR1-PR9) lebih tinggi dibandingkan dengan korelasi PR1-PR9 dengan Islamic branding dan kepuasan nasabah. Kemudian variabel kepuasan nasabah dengan indikator (KN1-KN15) lebih besar dibandingkan dengan korelasi PR1-PR15 dengan indikator lainnya yaitu Islamic branding dan perilaku religius. Hal ini membuktikan bahwa variabel laten (Islamic branding, perilaku religius dan kepuasan nasabah) memprediksi indikator pada blok masing-masing variabel dibandingkan dengan blok lainnya.

\section{Composite Reliability}

Kriteria reliabilitas dapat dilihat dari nilai reliabilitas suatu konstruk. Suatu konstruk yang memiliki reliabilitas yang tinggi apabila nilainya mencapai 0.70 . Nilai composite reliabilty disajikan dalam Tabel 3 berikut.

Tabel 3

Composite Reliability

\begin{tabular}{|l|c|}
\hline & Composite Reliability \\
\hline Islamic Branding & 0.947 \\
\hline Perilaku Religius & 0.968 \\
\hline Kepuasan Nasabah & 0.977 \\
\hline
\end{tabular}

Sumber : Pengolahan data dengan PLS, 2019

Berdasarkan Tabel 3 menunjukkan bahwa ketiga variabel tersebut yaitu Islamic branding, perilaku religius dan kepuasan nasabah memiliki nilai reliabilitas yang tinggi karena $>0.70$.

\section{Average Variance Extraced (AVE)}

Kriteria reliability juga dapat dilihat melalui nilai Average Variance Extracted (AVE). Suatu konstruk dinyatakan reliabel apabila nilainya berada diatas 0.50 . Pada Tabel 4 akan disajikan nilai Average Variance Extracted (AVE) seluruh variabel.

Tabel 4

Average Variance Extracted (AVE)

\begin{tabular}{|l|c|}
\hline & Average Variance Extracted (AVE) \\
\hline Islamic Branding & 0.667 \\
\hline Perilaku Religius & 0.773 \\
\hline Kepuasan Nasabah & 0.752 \\
\hline
\end{tabular}

Sumber : Pengolahan data dengan PLS, 2019 


\section{Cronbach's Alpha}

Uji reliabilitas diperkuat dengan cronbach's alpha dengan syarat nilai cronbach's alpha berada di atas 0.60 untuk semua konstruk. Pada tabel berikut akan disajikan nilai cronbach's alpha pada seluruh variabel.

\section{Tabel 5}

\begin{tabular}{|l|c|}
\multicolumn{2}{c}{ Cronbach's Alpha } \\
\hline \multicolumn{1}{|c|}{ Cronbach's Alpha } \\
\hline Islamic Branding & 0.938 \\
\hline Perilaku Religius & 0.963 \\
\hline Kepuasan Nasabah & 0.974 \\
\hline
\end{tabular}

Sumber : Pengolahan data dengan PLS, 2019

\section{Inner Model}

Pengujian inner model atau model struktural dilakukan untuk melihat hubungan antara konstruk, nilai signifikansi dan $R$-square dari model penelitian. Model struktural dievaluasi dengan menggunakan $R$-square untuk konstruk dependen uji t serta signifikansi dari koefisien parameter jalur struktural.

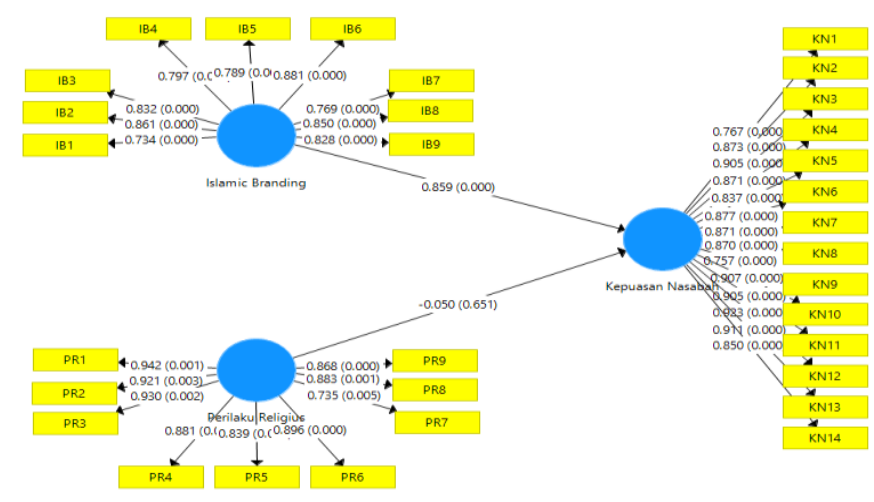

Gambar 2

Structural Model

Sumber : Bootsrapping SmartPLS 3.0

Tabel 6

Nilai $R$-Square

\begin{tabular}{|c|c|}
\hline Variabel & R-Square \\
\hline Kepuasan Nasabah & 0.706 \\
\hline
\end{tabular}

Sumber : Pengolahan data dengan PLS, 2019

Pada prinsipnya penelitian ini menggunakan 1 variabel yang dipengaruhi variabel lainnya yaitu kepuasan nasabah yang dipengaruhi oleh variabel Islamic branding dan perilaku religius. Pada Tabel 6 menunjukkan nilai $R$-square untuk variabel kepuasan nasabah dengan nilai 0.706 yang menunjukkan bahwa $70.6 \%$ dapat dipengaruhi oleh Islamic branding dan perilaku religius dan sisanya $29.4 \%$ dipengaruhi oleh faktor lain.

\section{Pengujian Hipotesis}

Untuk menilai signifikansi model prediksi dalam pengujian model struktural, dapat dilihat dari nilai $T$-statistic antara variabel independen ke variabel dependen dalam tabel path coefficient pada tabel dibawah ini: 
Tabel 7

Path Coefficients

\begin{tabular}{|c|c|c|c|c|c|}
\hline & $\begin{array}{c}\text { Original } \\
\text { Sample (O) }\end{array}$ & $\begin{array}{c}\text { Standard } \\
\text { Deviation }\end{array}$ & T-Statistics & P-Values & Keterangan \\
\hline $\begin{array}{c}\text { Islamic Branding-Kepuasan } \\
\text { Nasabah }\end{array}$ & 0.859 & 0.069 & 12.374 & 0.000 & Signifikan \\
\hline $\begin{array}{c}\text { Perilaku Religius-Kepuasan } \\
\text { Nasabah }\end{array}$ & -0.050 & 0.105 & 0.482 & 0.659 & Tidak Signifikan \\
\hline
\end{tabular}

Sumber : Pengolahan data dengan PLS, 2019

Sebelum dilakukan pengujian hipotesis, diketahui bahwa nilai nilai T-tabel untuk tingkat kepercayaan sebesar 95\% ( $\alpha$ sebesar 5\%) dan derajat kebebasan $(\mathrm{df})=\mathrm{n}-3=60-2=57$ adalah sebesar 2.002. Apabila nilai $T$-statistics $\geq 2.002$ maka hipotesis tersebut diterima sebaliknya apabila nilai $T$-statistics $\leq 2.002$ maka hipotesis ditolak.

Berdasarkan Tabel 7 dapat dilihat nilai original sample estimate Islamic branding adalah 0.859 dengan signifikansi di bawah 5\% yang ditunjukkan dengan nilai T-statistics Islamic branding 12.374>2.002. Nilai original sample estimate positif mengindikasikan bahwa Islamic branding berpengaruh positif terhadap kepuasan nasabah. Berdasarkan model regresi tersebut maka dapat disimpulkan bahwa hipotesis pertama diterima.

Berdasarkan Tabel 7 dapat dilihat nilai original sample estimate Perilaku Religius adalah 0.050 dengan signifikansi di atas $5 \%$ yang ditunjukkan dengan nilai $T$-Statistics perilaku religius $0.482<2.002$. Nilai original sample estimate yang negatif mengindikasikan bahwa perilaku religius tidak berpengaruh terhadap kepuasan nasabah. Berdasarkan model regresi tersebut maka dapat disimpulkan bahwa hipotesis kedua ditolak.

\section{Pembahasan}

\section{Pengaruh Islamic branding terhadap kepuasan nasabah Bank Syariah Mandiri Palu}

Berdasarkan hasil pengujian hipotesis pertama dalam penelitian ini dapat disimpulkan bahwa variabel Islamic branding berpengaruh positif terhadap kepuasan nasabah Bank Syariah Mandiri Palu. Hasil Penelitian ini sesuai dengan hasil penelitian yang dilakukan oleh Fithari (2017) mengenai "Pengaruh Islamic service dan Islamic branding terhadap kepuasan nasabah" yang menunjukkan bahwa Islamic branding memiliki pengaruh terhadap kepuasan nasabah.

Kepuasan dalam mengkonsumsi produk/jasa dikaitkan perasaan senang secara jasmaniah dan spiritual seseorang yang merasa tentram saat apa yang dikonsumsinya sesuai dengan apa yang menjadi prinsip hidupnya. Berdasarkan pendapat Fatema dalam Hafiz (2017:122) bahwa kepuasan spiritual konsumen muslim didapatkan dengan mengikuti pedoman syariah. Kosumen muslim perlu menyesuaikan produk/jasa yang dipilihnya dengan pedoman Islam agar memberikan kepuasan baik lahiriah maupun spiritual. Al-Ukhwah dalam Hafiz (2017:122) menyatakan bahwa suatu produk dengan Islamic branding harus halal dan tidak menimbulkan kebodohan fikiran sehingga kepuasan yang paling akhir adalah kepuasan secara lahiriah dan batiniah.

Islamic branding dibentuk dengan tujuan agar konsumen merasa puas karena kebutuhan lahiriah dapat terpenuhi dan juga merasakan ketentraman hati karena apa yang dikonsumsinya sesuai dengan syariat. Dengan mengikuti syariat Islam, nasabah menyadari bahwa Islamic branding merupakan kebutuhan yang bukan hanya berdasarkan faktor jasmani tetapi juga demi menjaga kesucian jiwa. Hasil penelitian ini menunjukkan bahwa dimensi merek fungsional pada Bank Syariah Mandiri Palu masih cukup rendah nilainya dibandingkan dimensi lainnya. Namun secara keseluruhan, Bank Syariah Mandiri Palu dalam pelaksanaan usahanya menjalankan 
Islamic branding dengan secara menyeluruh baik dari fungsional, sosial, mental dan spiritual. Hal ini menjadi salah satu faktor yang mempengaruhi tingkat kepuasan nasabah dalam penggunaan jasa perbankan di Bank Syariah Mandiri Palu.

\section{Pengaruh perilaku religius terhadap kepuasan nasabah Bank Syariah Mandiri Palu}

Penggunaan berbagai produk Islam membuat seseorang mengidentifikasi dirinya sebagai orang yang percaya dan hal ini memberikan citra yang positif bagi umat Islam. Menurut Amaliah et al. dalam Hafiz (2017:123) bahwa meningkatnya pemahaman mengenai nilai-nilai agama akan membuat seseorang mengerti pentingnya sebuah aktivitas/tindakan sebagai sumber penghidupan yang bermakna sebagai perintah agamanya yang akhirnya akan memberikan kepuasan bagi dirinya. Menurut Patel (2010), religiusitas adalah kekuatan budaya dan agama yang sangat penting dan memiliki potensi untuk mempengaruhi perilaku konsumen karena diperhatikan bahwa perilaku konsumen juga dikategorikan menurut keyakinan mereka. Tingkat religius dan tingkat pengaruh agama terhadap perilaku konsumen tergantung pada tingkat religiusitas mereka.

Berdasarkan pengujian hipotesis kedua dapat disimpulkan bahwa perilaku religius tidak berpengaruh pada kepuasan nasabah Bank Syariah Mandiri Palu. Hasil penelitian ini bertentangan dengan penelitian Mokhlis (2009) mengenai "Relevancy and Measurement of Religiosity in Consumer Behavior Research" di Malaysia yang menunjukkan bahwa religiusitas berpengaruh pada perilaku konsumen. Hasil penelitian ini juga bertentangan dengan penelitian yang dilakukan oleh Hafiz (2017) yang meneliti "Pengaruh Islamic branding dan perilaku religius terhadap kepuasan konsumen serta dampaknya pada loyalitas konsumen pada produk kosmetik Wardah" yang menghasilkan bahwa perilaku religius berpengaruh positif terhadap kepuasan konsumen Wardah.

Sebelumnya penelitian lain hanya menguji pengaruh perilaku religius terhadap kepuasan konsumen berbagai produk-produk dari industri makanan dan kosmetik sehingga belum ada penelitian yang meneliti pengaruh dari perilaku religius terhadap kepuasan konsumen terhadap penggunaan jasa seperti perbankan. Penelitian ini belum didukung oleh teori yang akurat mengenai pengaruh perilaku religius tehadap kepuasan nasabah bank syariah. Berdasarkan hasil penelitian ini, diketahui bahwa perilaku religius tidak memberikan kontribusi terhadap kepuasan nasabah Bank Syariah Mandiri Palu. Hal ini mengindikasikan bahwa nasabah Bank Syariah Mandiri Palu memiliki karakteristik yang cenderung berbeda dimana tingkat religiusitas nasabah bukan menjadi unsur utama dalam meningkatkan kepuasan mereka terhadap suatu produk/jasa yang mereka konsumsi. Dibanding tingkat religius mereka, nasabah lebih mempertimbangkan berbagai unsur lainnya sebagai hal yang sangat berkontribusi terhadap kepuasan mereka menggunakan jasa perbankan syariah.

\section{PENUTUP}

\section{Kesimpulan}

Penelitian ini bertujuan untuk menganalisis pengaruh Islamic branding dan perilaku religius terhadap kepuasan nasabah Bank Syariah Mandiri di Kota Palu. Untuk menganalisis hubungan antar variabel tersebut, penelitian ini menggunakan Partial Least Square (PLS). Berdasarkan hasil dan pembahasan pada bagian sebelumnya, maka dapat ditarik kesimpulan yaitu sebagai berikut:

1) Islamic branding berpengaruh signifikan terhadap kepuasan nasabah Bank Syariah Mandiri Palu.

2) Perilaku religius tidak berpengaruh signifikan terhadap kepuasan nasabah Bank Syariah Mandiri Palu. 


\section{Saran}

Berdasarkan hasil dari kesimpulan di atas, ada beberapa saran dari peneliti yang dapat dipertimbangkan yaitu:

1) PT. Bank Syariah Mandiri sebagai perusahaan jasa perbankan syariah yang memiliki merek Islami belum mampu menepis keraguan nasabah mengenai kesyariahannya sehingga PT. Bank Syariah Mandiri diharapkan mengembangkan merek Islami dengan cara memaksimalkan dimensi fungsionalnya sebagai bank syariah yang menunjukan nilai-nilai syariah dalam operasional, pelayanan serta produk-produk perbankan syariah.

2) Peneliti selanjutnya diharapkan dapat lebih dalam meneliti mengenai Islamic branding, perilaku religius dan kepuasan nasabah dengan menggunakan variabel-variabel lainnya serta mengembangkan penelitian dengan teori baru, metode, alat uji dan objek penelitian yang berbeda sebagai bahan perbandingan guna menambah referensi ilmu pengetahuan.

\section{REFERENSI}

Akbar, Y. J., \& Darmastuti, I. (2010). Analisis Pengaruh Motivasi Konsumen, Persepsi Kualitas, dan Sikap Konsumen Terhadap Keputusan Pembelian Sepeda Motor Honda (Studi Pada Konsumen Sepeda Motor Honda di Semarang). Semarang: Fakultas Ekonomi Universtas Diponegoro.

Alserhan, B. A. (2010). Islamic branding: A conceptualization of related terms. Journal of Brand Management, Vol. 18, No.1, pp.34-49.

Al-Quran dan terjemahannya. (2016). Departemen Agama Republik Indonesia. Yogyakarta: Balai Litbang LPTQ Nasional.

Arifin, L. N. (2017). Analisis Pegaruh Persepsi Kualitas, Islamic Branding, Dan Religiusitas Terhadap Keputusan Pembelian Kosmetik. Surakarta: Fakultas Ekonomi dan Bisnis Universitas Muhammadiyah.

Biesok, Grzegorsz dan Wrobel, Jolanta Wyrod. (2011). Customer Satisfaction-Meaning and Methods of Measuring. Marketing and logistic problems in the management of organization, pp.22-41.

Fithrati, N. (2017). Pengaruh Islamic Service Quality dan Islamic Branding terhadap Kepuasan Nasabah (Studi Kasus Pada Nasabah Bank Muamalat Indonesia). Jakarta: Fakultas Ekonomi dan Bisnis UIN Syarif Hidayatullah.

Fitriya, E. (2017). Analisis Pengaruh Islamic Branding Terhadap Keputusan Konsumen Untuk Membeli Produk. JIAI (Jurnal Ilmiah Akuntansi Indonesia), Vol.2 No.1, pp.31-41.

Hafiz, M. 2017. Pengaruh Islamic Branding dan Perilaku Religius terhadap Kepuasan Konsumen serta Dampaknya pada Loyalitas Konsumen pada Produk Kosmetik Wardah. Jakarta: Fakultas Ekonomi dan Bisnis UIN Syarif Hidayatullah.

Hakimi, N., Nawi, N. B. C., Ismail, M., Hasan, Z. M., Ibrahim, A. H., dan Nasir, N. A. B. M. (2018). The Roles of Islamic Religiosity, Brand Image and Knowledge on Relationship between Perceived Value and Tourist Satisfaction: A Review. International Journal of Business and Management, Vol.13, No.8, pp.101-107.

Khomariyah, N. (2017). Pengaruh Kesadaran Halal, Islamic Branding, dan Product Ingridient terhadap Minat Beli Produk Luwak White Koffie (Studi pada Masyarakat Desa Putatsewu, Jatitengah, Sukodono, Sragen). Surakarta: Fakultas Ekonomi dan Bisnis Islam Institut Agama Negeri Surakarta. 
Kotler, P., dan Armstrong, G. (2013). Principles of Marketing. Edisi ke-14. Edinburg: Pearson Education Limited.

Mihelis, G., Grigoroudis, E., Siskos, Y., Politis, Y., \& Malandrakis, Y. (2001). Customer satisfaction measurement in the private bank sector. European Journal of Operational Research, Vol.2, No.130, pp.347-360.

Mokhlis, Safiek. (2009). Relevancy and Measurement of Religiosity in Consumer Behavior Research. On International Business Research, Vol.2, No.3, pp.75-84.

Mourad, Maha \& Karanshawy, El Hatem. (2013). Branding Islamic studies: explonatory study in the Middle East. Journal of Islamic Marketing, Vol.4, No.2, pp.150-162.

Nasrullah, M. (2015). Islamic Branding, Religiusitas dan Keputusan Konsumen terhadap Produk. Jurnal Hukum Islam, Vol. 13, No.2, pp. 79-87.

Otoritas Jasa Keuangan. (2019). Statistik Perbankan Syariah per Juni 2019. Retrieved August 31, 2019, from https://ojk.go.id/id/kanal/syariah/data-dan-statistik/statistik-perbankansyariah/Default.aspx

Patel, M. (2010). Influence of Religion on Shopping Behavior of Consumers-an Exploratory Study. Journal of Research in Commerce \&Management, Vol.1, No.5, pp. 68-78.

Rahmawati, D. (2016). Pengaruh Korean Wave terhadap Country Image dan Intention to Buy Korean Product. Surabaya: Universitas Airlangga.

Saeed, M., Ahmed, Z. and Mukhtar, S. (2001). International marketing ethics from Islamic perspective: a value-maximization approach, Journal of Business Ethics, Vol. 32, pp. 127-142.

Schiffman,L.G dan Kanuk, Leslie Lazar. (2010). Consumer Behavior Tenth Edition. USA: Pearson Education.

Sugiyono. (2016). Metode Penelitian Kuantitatif, Kualitatif dan Kombinasi (Mixed Mothods). Bandung: Alfabeta.

Syariahmandiri.co.id. (2019). Tumbuh Semakin Sehat, Laba Mandiri Syariah Naik 12,22\% | Bank Syariah Mandiri. Retrieved February 11, 2019, from https://www.syariahmandiri.co.id/newsupdate/siaran-pers/tumbuh-semakin-sehat-laba-mandiri-syariah-naik-1222

Syariahmandiri.co.id. (2019). Tentang Kami | Bank Syariah Mandiri. Retrieved April 1, 2019, from https://www.syariahmandiri.co.id/tentang-kami/

Teresia. (2018). Analisis Faktor-Faktor yang Mempengaruhi Kepuasan Konsumen. Yogyakarta: Fakultas Ekonomi Universitas Sanata Dharma.

Top Brand Award. (2019). Tabungan Syariah 2019. Retrieved August 31, 2019, from Top Brand Award website: https://www.topbrand-award.com/en/2019/04/tabungan-syariah/

Usada, U., Hakim, L., dan Kurniawati, A.T. (2016). Analisis Pengaruh Kualitas Pelayanan Akademik terhadap Loyalitas Mahasiswa Unusida dengan pendekatan Partial Least Square (PLS). Journal of Research and Technology, Vol.2, No.2, pp.6-13.

Westbrook, R. A., dan Oliver, R. L. (1991). The dimensionality of consumption emotion patterns and consumer satisfaction. Journal of Consumer Research, Vol.18, No.1, pp.84-91.

Yee, C.J. dan San, N.C. (2011). Consumers' Perceived Quality. Perceived Value and Perceived Risk Towards Purchase Decision on Automobile. Journal of Economic and Business Administration, Vol.3, No.1, pp.47-57. 


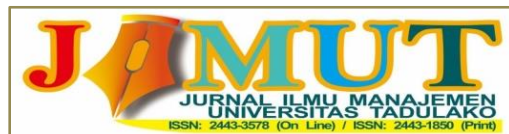

Vol. 7, No 3, Juli 2021, 225-236

Yunus, Wan, Norafifa, dan Norhidayah. (2013). Muslim's Purchase Intention towards Non-Muslim's Halal Packaged Food Manufacturer. Procedia - Social and Behavioral Sciences, 130, pp.145 154.

Yusof, Y. M., dan Jusoh, W. W. (2014). Islamic branding: The understanding and perception. Procedia-Social and Behavioral Sciences, 130, pp.179-185.

Zahara, Zakiyah. (2011). Penerapan Relationship Marketing dalam membangun Hubungan Kemitraan antara Nasabah dan Bank Syariah. Jurnal Aplikasi Manajemen, Vol.9, No.2, pp.101-117. 